\title{
ANALISIS PENERAPAN STANDAR AKUNTANSI PEMERINTAH TERHADAP ASET TETAP PEMERINTAH DAERAH KABUPATEN BOLAANG MONGONDOW
}

\author{
Enda Baisida Lauma, Jenny Morasa, Lintje Kalangi \\ (email: enda.lauma@gmail.com)
}

\begin{abstract}
Government Accounting Standard have changed from Cash Basis is to comply with the Government Regulation number 24 2005s to Government Regulation number 71 2010s. Requirement to implemented Accrual basis SAP by the Local Government was start in the Local Government Financial Statement for the year ended on December 2015s. The District Government of Bolaang Mongondow, before implemented accrual basis PP 71/2010 always received non-WTP opinion, because of asset problems. The objective of the research is to analyze the implementation of Government Accounting Standard to Fix Asset on the District Government of Bolaang Mongondow. The result of research indicate that although the District Government of Bolaang Mongondow has implemented the SAP based on accrual basis on this fix assets based on regulation (PP 71/2010) at Local Government Financial Statement Budget Year 2015s, it is found that financial statement still have constraints such differences in recording those assets between accounting division and assets division. In addition, there is non-current asset which do not master by SKPD, there is no information regarding existing assets, and some assets are also not clearly described. Those constraints have caused to gain Qualified Opinion of LKPD 2015s as audited by BPK.
\end{abstract}

Keywords : Implementation, Governmental Accounting Standard, Fix Asset.

\section{PENDAHULUAN}

Pertanggungjawaban Pemerintah Daerah dalam mengatur dan mengurus kepentingan pemerintahan dan masyarakatnya berbentuk Laporan keuangan dan laporan kinerja. Pemerintah pusat mengatur bahwa Laporan keuangan harus disusun dan disajikan sesuai dengan Standar Akuntansi Pemerintahan (SAP).

Laporan Keuangan Pemerintah Daerah (LKPD) Tahun 2015 harus menggunakan SAP berbasis akrual sesuai PP 71/2010, yaitu SAP yang mengakui pendapatan, beban, aset, hutang, dan ekuitas dalam pelaporan finansial berdasarkan basis akrual, serta mengakui pendapatan, belanja, dan pembiayaan dalam pelaporan pelaksanaan anggaran berdasarkan basis yang ditetapkan dalam Anggaran Pendapatan dan Belanja Negara/Anggaran Pendapatan dan Belanja Daerah (APBN/APBD). Menghadapi tuntutan aturan tersebut, dalam pencatatan aset pada LKPD, maka Pemda wajib mencantumkan nilai sewajarnya dari suatu aset. Penggunaan basis akrual berkaitan pula dengan penerapan penyusutan atas aset tetap.

Aset tetap merupakan bagian utama aset pemerintah daerah karena nilainya yang sangat signifikan dalam Neraca (Winarno, 2012:1). Penilaian aset sangat penting bukan saja dalam rangka pelaksanaan penghapusan dan pemindahtanganan aset/barang milik daerah yang dilelang/dijual, tetapi secara praktis memiliki hubungan langsung dengan, penyajian Neraca daerah. Menurut Setiadi (2008) jika aset tetap tidak dikelola dengan baik dapat mempengaruhi opini yang diberikan BPK, karena aset tetap merupakan komponen laporan keuangan yang signifikan. Perolehan opini atas LKPD Pemerintah Kabupaten Bolaang Mongondow sebelum penerapan PP71/2010 berbasis akrual belum mendapat opini WTP. Hasil evaluasi BPK yang termuat dalam setiap LHP dan termuat dalam beberapa Siaran Pers BPK Perwakilan Provinsi Sulawesi Utara yang menyatakan bahwa pemeriksaan meliputi penilaian atas penggunaan SAP oleh entitas dan penyajian laporan keuangan secara 
keseluruhan, bahwwa permasalahan yang menjadi dasar pertimbangan penetapan opini antara lain adalah masalah aset tetap.

Pemerintah Kabupaten Bolaang Mongondow, sebagaimana Pemda se-Indonesia, harus menerapkan PP 71/2010 yang berbasis akrual dalam penyusunan LKPD Tahun 2015. Aset yang disajikan Pemda, terdiri dari aset lancar dan aset tetap, harus disajikan dalam nilai yang wajar. Nilai wajar adalah nilai tukar aset atau penyelesaian kewajiban antar pihak yang memahami dan berkeinginan untuk melakukan transaksi wajar, sedangkan penyusutan adalah alokasi yang sistematis atas nilai suatu aset tetap yang dapat disusutkan (depreciable assets) selama masa manfaat aset yang bersangkutan. Jika nilai wajar aset telah dicantumkan dalam laporan keuangan, maka laporan tersebut sudah dapat dikatakan bisa dipercaya dan diandalkan.

Penelitian ini bertujuan untuk menganalisis penerapan Standar Akuntansi Pemerintah Terhadap Aset Tetap Pemerintah Daerah Kabupaten Bolaang Mongondow.

\section{TINJAUAN PUSTAKA}

\section{Teori Agensi (Agensy Theory)}

Jensen dan Meckling (1976: 308) menyatakan bahwa:

We define an agency relationship as a contract under which one or more persons (the principal(s)) engage another person (the agent) to perform some service on their behalf which involves delegating some decision making authority to the agent. If both parties to the relationship are utility maximizers there is good reason to believe that the agent will not always act in the best interests of the principal.

\section{Teori Aktiva (Asset)}

Kieso, Weygandt, dan Warfield (2012:216) mengatakan bahwa assets is probable future economic benefits obtained or controlled by a particular entity as a result of past transactions or events. Kata assets diartikan sebagai aktiva. Istilah "aktiva" yang masih banyak digunakan di Indonesia, pada awalnya, digunakan dalam Pernyataan Standar Akuntansi Keuangan Nomor 1 (Revisi 1998) kemudian direvisi menjadi "aset” oleh PSAK 1 (Revisi 2009). Warren et.al. (2005:21) menyatakan

the assets section of the balance sheet normally presents assets in the order that they will be converted into cash or used in operations. Cash is presented first, followed by receivables, supplies, prepaid insurance, and other assets. The assets of a more permanent nature are shown next, such as land, buildings, and equipment.

PSAK 16 (Revisi 2011) mendefinisikan aset tetap sebagai aset berwujud yang dimiliki untuk digunakan dalam produksi atau penyediaan barang atau jasa untuk direntalkan kepada pihak lain, atau untuk tujuan administratif dan diharapkan untuk digunakan selama lebih dari satu periode. Aset tetap dikelompokkan berdasarkan kepemilikan sifat dan kegunaan yang serupa dalam operasi normal entitas, contohnya tanah, tanah dan bangunan, mesin, kapal, pesawat udara, kendaraan bermotor, perabotan, dan peralatan kantor.

\section{Teori Aktiva Tetap (Fix Asset)}

Baridwan (2004:22) mendefinisikan aktiva tetap sebagai aktiva-aktiva yang dapat digunakan lebih dari satu periode, seperti tanah, gedung-gedung, mesin dan alat-alat, perabot, kendaraan, dan lain-lain. Suatu aktiva diakui sebagai aktiva tetap menurut Darise (2008:71) jika aset tersebut berwujud dan memenuhi kriteria berikut: mempunyai manfaat lebih dari 12 (dua belas) bulan, biaya perolehan aset dapat diukur secara andal, tidak dimaksudkan untuk dijual dalam operasi normal entitas, serta diperoleh atau dibangun dengan maksud untuk digunakan. 
PSAK 16 menyebutkan bahwa aset tetap yang memenuhi kualifikasi pengakuan sebagai aset diukur pada biaya perolehan. Biaya historis (historical cost) diukur oleh kas atau harga ekuivalen kas untuk memperoleh aktiva dan membawanya ke lokasi serta kondisi yang diperlukan untuk tujuan penggunaannya. Jika suatu aktiva tetap diperoleh tanpa nilai, maka menurut Darise (2008:72) aktiva tetap tersebut diukur berdasarkan nilai wajar saat perolehan, yaitu nilai tukar aset atau penyelesaian kewajiban antar pihak yang memahami dan berkeinginan untuk melakukan transaksi wajar.

Dalam menilai aset tetap Chan dan Zhang (2012:13) menyatakan bahwa Non-financial assets are stated in terms of their original acquisition costs (sometimes called historical cost) adjusted for depreciation. Selain tanah dan konstruksi dalam pengerjaan, seluruh aset tetap dapat disusutkan sesuai dengan sifat dan karakteristik aset tersebut (Darise, 2008:78). Penyusutan (depreciation) adalah proses akuntansi dalam mengalokasikan biaya aktiva berwujud ke beban dengan cara yang sistematis dan rasional selama periode yang diharapkan mendapat manfaat dari penggunaan aktiva tersebut (Kieso et.al., 2008:60). PSAK 16 (p.16.7) mengatur bahwa setiap bagian dari aset tetap yang memiliki biaya perolehan cukup signifikan terhadap total biaya perolehan seluruh aset tetap disusutkan secara terpisah. Dampak signifikan dari metode penyusutan yang digunakan terhadap laporan keuangan, menurut Kieso et.al. (2008:85) harus dibuat pengungkapan terkait: Beban penyusutan untuk periode berjalan; Saldo kelas utama dari aktiva yang dapat disusutkan, menurut sifat dan fungsi; Akumulasi penyusutan, baik menurut kelas utama aktiva yang dapat disusutkan maupun dalam jumlah total; serta Sesuai uraian umum tentang metode yang digunakan dalam menghitung penyusutan berkaitan dengan kelas utama aktiva yang dapat disusutkan.

\section{Standar Akuntansi Pemerintahan}

Salah satu aspek penting untuk meningkatkan kualitas tata kelola keuangan negara dan pelaporan keuangan pemerintahan adalah penggunaan SAP (Mahmudi, 2011:271). Standar akuntansi menurut Mardiasmo (2009:149) diperlukan untuk menjamin konsistensi dalam pelaporan keuangan. Tidak adanya standar akuntansi yang memadai akan menimbulkan implikasi negatif berupa rendahnya reliabilitas dan objektivitas informasi yang disajikan, inkonsistensi dalam pelaporan keuangan serta menyulitkan dalam pengauditan.

Undang-undang Keuangan Negara telah mengantisipasi perubahan standar akuntansi di lingkungan pemerintahan yang mengacu pada perkembangan standar akuntansi di lingkungan pemerintahan secara internasional (Darise, 2008:4). Pasal 32 UU 17/2003 menyatakan bahwa bentuk dan isi laporan pertanggungjawaban pelaksanaan APBN/APBD disusun dan disajikan sesuai dengan SAP. PP 71/2010 mendefinisikan Standar Akuntansi Pemerintahan sebagai prinsip-prinsip akuntansi yang diterapkan dalam menyusun dan menyajikan laporan keuangan pemerintah.

SAP berisi prinsip-prinsip akuntansi yang menurut Mahmudi (2011:271) diterapkan dalam menyusun dan menyajikan laporan keuangan pada organisasi pemerintahan. Manfaat adanya standar akuntansi ini antara lain: digunakan oleh akuntan keuangan di pemerintahan sebagai pedoman dalam peyusunan dan penyajian laporan keuangan pemerintahan; digunakan oleh auditor sebagai kriteria audit untuk menentukan apakah laporan keuangan yang disajikan sudah sesuai dengan standar akuntansi yang mengaturnya; digunakan oleh pengguna laporan keuangan untuk memahami laporan keuangan dan menghindari kesalahan dalam menginterpretasikan informasi dalam laporan keuangan; diperlukan untuk meningkatkan kualitas laporan keuangan yaitu meningkatkan konsistensi, daya banding, keterpahaman, relevansi dan keandalan laporan keuangan; serta menjadi acuan dalam penyusunan sistem akuntansi sebab keluaran sistem akuntansi harus sesuai dengan standar akuntansi. 
Akuntansi aset tetap dalam PP 71/2010 dimuat pada Lampiran I.08 PSAP No.07 Akuntansi Aset Tetap, dilengkapi dengan Bultek 15 tentang Akuntansi Aset Tetap Berbasis Akrual dan Bultek 18 tentang Penyusutan Aset Tetap Berbasis Akrual. Isi pokok dari SAP mengatur tentang: definisi, pengakuan, pengukuran, penilaian, dan pengungkapan suatu transaksi atau akun.

\section{Laporan Keuangan Pemerintah Daerah}

Pelaporan keuangan daerah menurut Yuwono, Utomo, Zein, dan Azrafiany (2008:429) merupakan laporan pertanggungjawaban Pemerintah Daerah atas kegiatan keuangan dan sumber daya ekonomi yang dikelola serta menunjukkan posisi keuangan yang sesuai dengan kebijakan akuntansi keuangan daerah selama satu periode tertentu.

Entitas pelaporan menurut Darise (2008:258) membuat laporan keuangan pemerintah yang dilakukan dengan menggabungkan/mengkompilasi seluruh laporan keuangan Satuan Kerja Perangkat Daerah (SKPD) dan laporan keuangan Bendahara Umum Daerah (BUD). Tujuannya adalah menyajikan informasi mengenai posisi keuangan, realisasi anggaran, saldo anggaran lebih, arus kas, hasil operasi, perubahan ekuitas suatu entitas pelaporan yang bermanfaat bagi para pengguna dalam membuat dan mengevaluasi keputusan mengenai alokasi sumber daya.

Komponen laporan keuangan berdasarkan PP 71/2010 dan menurut Yuwono et.al. (2008:144) meliputi Laporan Posisi Keuangan (Neraca), Laporan Realiasi Anggaran (LRA), Laporan Operasional (LO), Laporan Perubahan Saldo Anggaran Lebih (LPSAL), Laporan Perubahan Ekuitas (LPE), Laporan Arus Kas (LAK), dan Catatan atas Laporan Keuangan (CaLK). Setiap entitas pelaporan harus menyajikan laporan-laporan tersebut, kecuali LAK dan LPSAL. Karena LAK hanya disajikan oleh entitas yang mempunyai fungsi perbendaharaan umum, sedangkan LPSAL hanya disajikan oleh Bendahara Umum Negara (BUN) dan entitas pelaporan yang menyusun laporan keuangan konsolidasiannya.

Pemerintah daerah membuat LKPD berdasarkan SAP dengan tujuan untuk memperoleh opini wajar atas peyajian laporannya. Opini wajar diistilahkan dengan pendapat Wajar Tanpa Pengecualian (WTP). Darise (2008:269) menjelaskan bahwa pendapat WTP diberikan oleh auditor jika tidak terjadi pembatasan dalam lingkup audit dan tidak terdapat pengecualian yang signifikan mengenai kewajaran dan penerapan prinsip akuntansi berterima umum dalam penyusunan laporan keuangan, konsistensi penerapan prinsip akuntansi berterima umum tersebut, serta pengungkapan memadai dalam laporan keuangan. Laporan keuangan dianggap menyajikan secara wajar posisi keuangan dan hasil usaha suatu organisasi, sesuai dengan prinsip akutansi berterima umum, jika memenuhi kondisi:

1. Prinsip akuntansi berterima umum digunakan untuk menyusun laporan keuangan;

2. Perubahan penerapan prinsip akuntansi berterima umum dari periode ke periode telah cukup dijelaskan;

3. Informasi dalam catatan-catatan yang mendukungnya telah digambarkan dan dijelaskan dengan cukup dalam laporan keuangan, sesuai dengan prinsip akuntansi berterima umum.

\section{Konsep Aset Pemerintah}

Aset pemerintah yang termuat dalam laporan keuangan (Neraca), didefinisikan oleh PP 71/2010 dan Darise (2008:59) sebagai sumber daya ekonomi yang dikuasai dan/atau dimiliki pemerintah akibat dari peristiwa masa lalu dan dari mana manfaat ekonomi dan/atau sosial di masa depan diharapkan dapat diperoleh, baik oleh pemerintah maupun masyarakat, serta dapat diukur dalam satuan uang, termasuk sumber daya nonkeuangan yang diperlukan untuk penyediaan jasa bagi masyarakat umum dan sumber-sumber daya yang dipelihara karena alasan sejarah dan budaya. 
Aset diklasifikasikan berdasarkan kesamaan dalam sifat dan fungsinya (Tanjung, 2008:214) ke dalam aset lancar dan non-lancar, di mana aktiva tetap merupakan salah satu dari aset non-lancar (Darise, 2008:60). PSAP 07 menerangkan bahwa aktiva tetap adalah aset berwujud yang mempunyai masa manfaat lebih dari 12 (dua belas) bulan untuk digunakan, atau dimaksudkan untuk digunakan dalam kegiatan pemerintah atau dimanfaatkan oleh masyarakat umum. Aset tetap sering merupakan suatu bagian utama aset pemerintah dan karenanya signifikan dalam penyajian Neraca (Darise, 2008:70). Aktiva tetap pemerintah daerah diklasifikasikan menjadi: (a) tanah, (b) peralatan dan mesin, (c) gedung dan bangunan, (d) jalan, irigasi, dan jaringan, (e) aset tetap lainnya, dan (f) konstruksi dalam pengerjaan (Darise, 2008:60, Permendagri 17/2007, dan PSAP 07).

KPP71/2010 menyatakan bahwa pengakuan aset tetap akan sangat andal bila aset tetap telah diterima atau diserahkan hak kepemilikannya dan atau pada saat penguasaannya berpindah. Saat pengakuan aset akan dapat diandalkan apabila terdapat bukti bahwa telah terjadi perpindahan hak kepemilikan dan/atau penguasaan secara hukum, misalnya sertifikat tanah dan bukti kepemilikan kendaraan bermotor. Apabila perolehan aset tetap belum didukung dengan bukti secara hukum dikarenakan masih adanya suatu proses administrasi yang diharuskan, seperti pembelian tanah yang masih harus diselesaikan proses jual beli (akta) dan sertifikat kepemilikannya di instansi berwenang, maka aset tetap tersebut harus diakui pada saat terdapat bukti bahwa penguasaan atas aset tetap tersebut telah berpindah, misalnya telah terjadi pembayaran dan penguasaan atas sertifikat tanah atas nama pemilik sebelumnya.

Pengukuran menurut PP 71/2010 sebagai proses penetapan nilai uang untuk mengakui dan memasukkan setiap pos dalam laporan keuangan. Pengukuran pos-pos dalam laporan keuangan menggunakan nilai perolehan historis. Aset dicatat sebesar pengeluaran/penggunaan sumber daya ekonomi atau sebesar nilai wajar dari imbalan yang diberikan untuk memperoleh aset tersebut. Pengukuran dan penilaian aset tetap dinilai dengan biaya perolehan, bila tidak memungkinkan maka nilai aset tetap didasarkan pada nilai wajar pada saat perolehan (Mahmudi, 2011:291 dan PP71/2010). Biaya perolehan menurut Darise (2008:72) adalah jumlah kas atau setara kas yang dibayarkan atau nilai wajar imbalan lain yang diberikan untuk memperoleh suatu aset pada saat perolehan atau konstruksi sampai dengan aset tersebut dalam kondisi dan tempat yang siap untuk digunakan.

PP71/2010 menyebutkan bahwa aset tetap yang diperoleh tanpa nilai, maka biaya aset tersebut adalah sebesar nilai wajar pada saat aset tersebut diperoleh. Penggunaan nilai wajar pada saat perolehan menurut Darise (2008:72) bukan merupakan suatu proses penilaian kembali (revaluasi). Penilaian kembali hanya diterapkan pada penilaian untuk periode pelaporan selanjutnya, bukan pada saat perolehan awal.

PP71/2010 menyatakan bahwa untuk masing-masing jenis aset tetap suatu laporan keuangan harus mengungkapkan: (a) Dasar penilaian yang digunakan untuk menentukan nilai tercatat (carrying amount); (b) Rekonsiliasi jumlah tercatat pada awal dan akhir periode yang menunjukkan penambahan, pelepasan, akumulasi penyusutan dan perubahan nilai (jika ada), dan mutasi aset tetap lainnya; serta (c) Informasi penyusutan, meliputi nilai penyusutan, metode penyusutan yang digunakan, masa manfaat atau tarif penyusutan yang digunakan, serta nilai tercatat bruto dan akumulasi penyusutan pada awal dan akhir periode.

Dampak signifikan dari metode penyusutan yang digunakan terhadap laporan keuangan menurut Kieso et.al. (2008:85) harus mengungkapkan: (a) Beban penyusutan untuk periode berjalan, (b) Saldo kelas utama dari aktiva yang dapat disusutkan, menurut sifat dan fungsi, (c) Akumulasi penyusutan, baik menurut kelas utama aktiva yang dapat disusutkan maupun 
dalam jumlah total, (d) Sesuai uraian umum penggunaan metode dalam menghitung penyusutan berkaitan dengan kelas utama aktiva yang dapat disusutkan.

Laporan keuangan juga, menurut Mahmudi (2011:295), harus mengungkapkan eksistensi dan batasan hak milik atas aset tetap, kebijakan akuntansi untuk kapitalisasi yang berkaitan dengan aset tetap, jumlah pengeluaran pada pos aset tetap dalam konstruksi, dan jumlah komitmen untuk akuisisi aset tetap. Jika aset tetap dicatat pada jumlah yang dinilai kembali, maka menurut Darise (2008:78) harus diungkapkan dasar peraturan untuk menilai kembali aset tetap, tanggal efektif penilaian kembali, nama penilai independen (jika ada), hakikat setiap petunjuk yang digunakan untuk menentukan biaya pengganti, serta nilai tercatat setiap jenis aset tetap.

Terhadap aset tetap yang tidak digunakan lagi harus dieliminasi dari neraca. PSAP 07 mengatur bahwa aset tetap dieliminasi dari neraca ketika dilepaskan atau bila secara permanen aset tersebut dihentikan penggunaannya dan tidak ada manfaat ekonomik masa yang akan datang. Aset yang dilepaskan, diungkapkan dalam CaLK.

\section{Penyusutan Aset Tetap Pemerintah}

Penyusutan penting diperhatikan selama pemanfaatan suatu aset tetap (Ramadhan, 2013:3). Bagi para akuntan, penyusutan bukan merupakan masalah penilaian, namun merupakan alat alokasi biaya (Kieso et.al., 2008:60). Penyusutan menurut PSAP 07 adalah alokasi yang sistematis atas nilai suatu aset tetap yang dapat disusutkan (depreciable assets) selama masa manfaat aset yang bersangkutan. Nilai penyusutan untuk masing-masing periode diakui sebagai pengurang nilai tercatat aset tetap dalam neraca dan beban penyusutan dalam laporan operasional.

Penyusutan aktiva pada Pemerintah Daerah di Indonesia diatur dengan Peraturan Menteri Keuangan Nomor 1/PMK.06/2013. Aturan tersebut digunakan untuk mendukung UndangUndang Nomor 36 Tahun 2008 dan Lampiran I.08 PP 71/2010. Pemerintah menggunakan Buletin Teknis SAP Nomor 18 sebagai dasar penyusutan dan metodenya, sedangkan untuk menilai aset digunakan Peraturan Menteri Keuangan Nomor 166/PMK.06/2015.

Aset tetap merupakan komponen aset operasi pemerintah yang penting dalam menjalankan operasional pemerintahan. Aset tetap memiliki sifat yang rentan terhadap penurunan kapasitas sejalan dengan penggunaan atau pemanfaatannya. Oleh karena itu pemerintah harus menyajikan informasi tentang nilai aset tetap secara memadai agar dapat digunakan untuk pengambilan keputusan dalam pengelolaan aset (Bultek SAP 18).

Penyusutan BMN berupa Penyusutan Aset Tetap menurut Permenkeu 1/PMK.06/2013 adalah penyesuaian nilai sehubungan dengan penurunan kapasitas dan manfaat dari suatu aset, yang dilakukan untuk dapat menyajikan nilai Aset Tetap secara wajar sesuai dengan manfaat ekonomi aset dalam laporan keuangan pemerintah pusat. Penyusutan terhadap aset ini dilakukan untuk dapat mengetahui potensi BMN dengan memperkirakan sisa Masa Manfaatnya yang diharapkan masih dapat diperoleh dalam beberapa tahun ke depan. Penyusutan juga dilakukan untuk dapat memberikan bentuk pendekatan yang lebih sistematis dan logis dalam menganggarkan belanja pemeliharaan atau belanja modal untuk mengganti atau menambah Aset Tetap yang sudah dimiliki.

Masa manfaat atau periode di mana suatu Aset Tetap diharapkan digunakan untuk aktivitas pemerintahan dan/atau pelayanan publik atau jumlah produksi atau unit serupa yang diharapkan diperoleh dari aset untuk aktivitas pemerintahan dan/atau pelayanan publik (Permenkeu 1/PMK.06/2013) diatur secara rinci dalam UU 36/2008. UU 36/2008 mengatur masa manfaat serta tarif penyusutan 


\section{PERTANYAAN RISET DAN PROPOSISI}

Pertanyaan riset: Bagaimana penerapan Standar Akuntansi Pemerintah terhadap aset tetap Pemerintah Daerah Kabupaten Bolaang Mongondow.

Proposisi: Apabila Standar Akuntansi Pemerintah diterapkan sesuai dengan PP 71/2010 terhadap Aset Tetap, maka pengakuan, pengukuran, pengklasifikasian, penyajian dan pengungkapan aset tetap dapat diyakini kewajarannya sehingga Pemerintah Daerah bisa memperoleh opini WTP.

\section{METODE PENELITIAN Jenis Data}

Data yang digunakan dalam penelitian ini adalah data kuantitatif daan data kualitatif. Data kuantitatif yakni angka-angka aset tetap yang tertuang dalam Laporan Barang Milik Daerah (LBMD) Tahun 2015 dan Laporan Keuangan Pemerintah Daerah Tahun Anggaran 2015 Data kualitatif yakni uraian Catatan atas Laporan Keuangan Pemerintah Daerah Tahun 2015 dan hasil wawancara yang memberi keyakinan mengenai penerapan akuntansi berbasis akrual terhadap aset tetap.

\section{Sumber Data}

Sumber data dalam penelitiaan ini adalah data primer dan data sekunder. Data primer berupa hasil wawancara dengan Bagian Aset dan Bagian Akuntansi pada DPPKAD Kabupaten Bolaang Mongondow berdasarkan daftar pertanyaan. Data sekunder berupa dokumen Laporan Keuangan Pemerintah Daerah (LKPD) dan dokumen aset yang tertuang dalam LBMD Pemerintah Kabupaten Bolaang Mongondow, serta berbagai referensi berupa dokumen-dokumen peraturan perundang-undangan yang berkaitan dengan Standar Akuntansi Pemerintahan, Sistim Akuntansi, Kebijakan Akuntansi, dan profil daerah.

\section{Teknik Pengumpulan Data}

Teknik pengumpulan data yang dilakukan dalam penelitian yaitu

1. Studi Dokumentasi, yaitu mengumpulkan dan menganalisa dokumen yang menyajikan aset tetap Tahun 2015 dari Pemerintah Kabupaten Bolaang Mongondow.

2. Wawancara

Wawancara, yaitu kegiatan berhadapan langsung dengan informan untuk mendapatkan informasi penelitian secara lisan dan sebagai alat rechecking atau pembuktian terhadap informasi yang diperoleh sebelumnya serta untuk menemukan informasi terkait kendala dalam penerapan SAP sesuai PP 71/2010

\section{Metode Analisis Data}

Data yang diperoleh dianalisa menggunakan metode penelitian deskriptif kualitatif dalam bentuk studi kasus yaitu menganalisis kesesuaian penerapan akuntansi aset tetap dalam LKPD dan LBMN Pemerintah Kabupaten Bolaang Mongondow, dengan Standar Akuntansi Pemerintahan menurut PP 71/2010. Untuk mendukung analisa dari findings penelitian ini dilakukan wawancara terhadap key persons guna menjustifikasi hasil analisa dari findings terhadap data sekunder. Hasil wawancara dianalisa dengan menggunakan content analysis.

\section{HASIL ANALISIS DAN PEMBAHASAN \\ Hasil Penelitian}

LKPD adalah laporan keuangan pemerintah daerah yang berisi rangkaian laporan terdiri atas Laporan Realisasi Anggaran PPKD, Neraca PPKD, Laporan Arus Kas, Laporan Perubahan Saldo Anggaran Lebih, Laporan Operasional, Laporan Perubahan Ekuitas dan Catatan atas Laporan Keuangan. Laporan tentang Aset Pemerintah Kabupaten Bolaang Mongondow disajikan dalam Neraca. 
LBMD adalah Laporan Barang Milik Daerah yang merupakan rangkaian tabel berisi angka nilai aset, yang terdiri atas Aset Tetap Tanah, Aset Tetap Peralatan dan Mesin, Aset Tetap Gedung dan Bangunan, Aset Tetap Jalan, Irigasi dan Jaringan, Aset Tetap Lainnya, serta Konstruksi Dalam Pengerjaan.

Pemerintah Kabupaten Bolaang Mongondow menerapkan Standar Akuntansi Pemerintahan Berbasis Akrual terhadap aset tetap, dalam hal pengakuan, pengukuran, dan pengklasifikasian, penyajian dan pengungkapan dalam LKPD. LKPD yang dihasilkan selanjutnya harus direkonsiliasi dengan data aset yang disajikan dalam LBMD, untuk menyesuaikan data yang ada pada Bagian Aset dan Bagian Akuntansi.

\section{Analisa Penerapan Standar Akuntansi Pemerintahan terhadap Aset Tetap Pemerintah Kabupaten Bolaang Mongondow Tahun 2015}

Pemerintah Kabupaten Bolaang Mongondow, mengakui suatu aset sebagai aset tetap jika dikuasai dan dimilikinya, dengan memperhatikan keberwujudan aset dimaksud, manfaat ekonomik yang dapat diperoleh, masa manfaatnya yang lebih dari 12 (dua belas) bulan, serta biaya perolehannya dapat diukur dengan andal, dan diperoleh untuk digunakan dalam operasionalisasi pemerintahan. Sebagaimana diatur oleh PP 71/2010.

Setelah proses pengukuran, aset tetap Pemerintah Kabupaten Bolaang Mongondow diklasifikasikan berdasarkan kesamaan sifat dan fungsinya, sesuai dengan SAP PP 71/2010, terdiri atas Tanah, Peralatan dan Mesin, Gedung dan Bangunan, Jalan, Irigasi dan Jaringan, Aset Tetap Lainnya, dan Konstruksi Dalam Pengerjaan. Klasifikasi aset tetap ini disajikan dalam Neraca dan LBMD.

LKPD Pemerintah Kabupaten Bolaang Mongondow Tahun 2015 sudah mencantumkan nilai penyusutan. Nilai penyusutan ini dihitung secara manual menggunakan Microsoft excel dan tidak menggunakan aplikasi yang ada yaitu Simda-BMD. Nilai penyusutan yang dihitung adalah akumulasi penyusutan aset tetap sampai dengan Tahun 2014 dan beban penyusutan aset tetap untuk Tahun 2015. Namun hasil perhitungan penyusutan sampai dengan Tahun 2014 tidak dicantumkan ke dalam laporan keuangan.

Berdasarkan uraian di atas dapat dianalisa bahwa Pemerintah Kabupaten Bolaang Mongondow dalam mengakui suatu aset sebagai aset tetap telah menerapkan sesuai SAP PP $71 / 2010$, yaitu pengakuan nilai tercatat dan penyusutannya. Namun penerapan tersebut masih terkendala dengan tidak disajikannya nilai penyusutan dan akumulasi penyusutan Tahun 2014 pada Neraca Tahun 2014.

Analisa untuk setiap klasifikasi aset tetap pada Pemerintah Kabupaten Bolaang Mongondow adalah:

1. Aset Tetap Tanah

Pengakuan Aset Tetap Tanah Pemerintah Kabupaten Bolaang Mongondow belum memenuhi semua kriteria SAP PP71/2010. Hal ini dikarenakan masih ada perbedaan nilai antara Bagian Akuntansi dengan Bagian Aset, diakibatkan oleh penyerahan aset ke daerah pemekaran. Dalam hal penyesuaian nilai asset melalui reklasifikasi dan kapitalisasi atas Aset Tetap Tanah sudah mengikuti ketentuan PP 71/2010.

2. Aset Tetap Peralatan dan Mesin

Pemerintah Daerah Kabupaten Bolaang Mongondow dalam menerapkan SAP terhadap Aset Tetap Peralatan dan Mesin miliknya untuk Tahun 2015 sudah menggunakan PP 71/2010 dengan diberlakukannya penyesuaian melalui reklasifikasi dan kapitalisasi atas aset tersebut. Baik itu reklasifikasi ke dalam Aset Tetap Peralatan dan Mesin maupun reklasifikasi ke luar aset tersebut. Kekurangannya bahwa dalam penyusunan laporan Tahun 2015 tidak ditelusuri dan disesuaikan nilai minus dari Aset Tetap Peralatan dan Mesin, sehingga hal ini menjadi temuan BPK. 
Penundaan penelusuran nilai minus aset ini, mencerminkan fenomena proprastinasi pada Pemerintah Daerah kabupaten Bolaang Mongondow. Sebagaimana dijelaskan oleh Ibrahim (2015) bahwa dalam hal penerapan akuntansi akrual terjadi fenomena prokrastinasi pada kebanyakan pemerintah daerah di Indonesia. Padahal terkait aset, standar akuntansi menyebutkan bahwa aset bersaldo debet, jadi tidak bisa negatif. Hal ini tidak sejalan dengan keharusan dalam teori agensi (agency theory), bahwa akuntabilitas publik dimaknai dengan adanya kewajiban pihak pemegang amanah (agent) untuk memberikan pertanggungjawaban, menyajikan, melaporkan, dan mengungkapkan segala aktivitas dan kegiatan yang menjadi tanggungjawabnya kepada pihak pemberi amanah (principal) yang memiliki hak dan kewenangan untuk meminta pertanggungjawaban tersebut (Haryanto et al, 2007 dalam Faristina, 2011).

3. Aset Tetap Gedung dan Bangunan

Biaya perolehan gedung dan bangunan Pemerintah Kabupaten Bolaang Mongondow merupakan biaya perolehan sesuai yang dimaksudkan dalam par.32 PSAP 07 PP 71/2010. Namun masih ada beberapa masalah tetapi sudah diperbaiki, berupa salah klasifikasi sehingga sudah direklasifikasi. Seperti reklasifikasi dari aset yang lain, reklasifikasi dari Aset Tetap Konstruksi Dalam Pengerjaan, serta reklasifikasi dari belanja barang dan jasa. Penyusutan dihitung menggunakan metode garis lurus dengan bantuan aplikasi Microsoft excel dan bukan menggunakan aplikaasi Simda BMD.

4. Aset Tetap Jalan, Irigasi dan Jaringan`

Pemerintah Kabupaten Bolaang Mongondow mencatat biaya perolehan Aset Tetap Jalan, Irigasi dan Jaringan yang menggambarkan seluruh biaya yang dikeluarkan dan yang masih harus dikeluarkan untuk memperoleh jalan, irigasi, dan jaringan sampai siap pakai. Biaya ini meliputi biaya perolehan atau biaya konstruksi dan biaya-biaya lain yang dikeluarkan sampai jalan, irigasi dan jaringan tersebut siap pakai. Sedangkan penyusutan Aset Tetap Jalan, Irigasi dan Jaringan, dihitung berdasarkan harga perolehan Perhitungan dilakukan untuk perolehan sampai dengan Tahun 2014 guna mendapatkan akumulasi penyusutan awal periode 2015, perhitungan beban penyusutan untuk Tahun 2015, serta nilai buku pada akhir periode 2015, dengan menggunakan metode garis lurus, didasarkan dengan aturan dalam Bultek SAP 18.

5. Aset Tetap Lainnya

Pemerintah Kabupaten Bolaang Mongondow menyajikan Aset Tetap Lainnya sesuai pengklasifikasian yang dimaksud oleh PP 71/2010 dan Bultek SAP 15, yaitu aset tetap yang tidak dapat dikelompokkan ke dalam kelompok aset tetap tanah, gedung dan bangunan, peralatan dan mesin, serta jalan, irigasi dan jaringan, yang diperoleh dan dimanfaatkan untuk kegiatan operasional pemerintah dan dalam kondisi siap pakai. Aset ini terdiri atas buku, barang bercorak kebudayaan dan alat olah raga, serta renovasi aset dan belanja hewan.

6. Aset Tetap Konstruksi Dalam Pengerjaan

Kabupaten Bolaang Mongondow menyajikan data Aset Tetap Konstruksi Dalam Pengerjaan milik Pemerintah Kabupaten Bolaang Mongondow, yang pengakuan dan pencatatannya sudah mengikuti PP 71/2010 yaitu mencatat aset yang belum selesai pengerjaannya pada tanggal pelaporan.

Namun dari penjelasan aset ini pada CaLK terlihat bahwa tidak ada keterangan mengenai rincian kontrak konstruksi dalam pengerjaan berikut tingkat penyelesaian dan jangka waktu penyelesaian pada tanggal neraca, nilai kontrak konstruksi dan sumber pembiayaannya, uang muka kerja yang diberikan sampai dengan tanggal neraca, jumlah retensi. 
Dalam perspektif teori agensi, Pemerintah Kabupaten Bolaang Mongondow merupakan agent dan masyarakat sebagai principal. Pemerintah Daerah (agent) bertanggungjawab kepada masyarakat (principal) sebagai pemberi amanah dalam pelaksanaan tugas pemerintahan di daerah, dengan membuat pertanggungjawaban dalam bentuk LKPD dan LBMD. Pemerintah Daerah sebagai agent harus menerapkan SAP terhadap aset tetap daerah untuk LKPD dan LBMD, sehingga laporan yang dihasilkan agent dapat diyakini kewajarannya.

Pemerintah Kabupaten Bolaang Mongondow melalui Bagian Aset dan Bagian Akuntansi DPPKAD telah mengkompilasi data aset dari semua SKPD yang ada pada pemerintahan Kabupaten Bolaang Mongondow. Aset-aset tersebut telah diklasifikasikan berdasarkan kesamaan dalam sifat atau fungsinya dalam aktivitas operasi entitas sesuai PP 71/2010. Proses ini dilakukan di DPPKAD karena di SKPD masih terkendala pada SDM dan Aplikasi Simda-BMD yang digunakan tidak dapat maksimal untuk menyajikan nilai aset.

Untuk kepentingan pencantuman nilai aset dalam LKPD 2015, Bagian Aset DPPKAD meninjau kembali pengakuan aset dan pengukurannya. Sehingga ada beberapa aset yang nilainya direklasifikasi dan dikapitalisasi sebelum dilakukan perhitungan penyusutan. Seperti penambahan harga perolehan aset tetap selain karena ada realisasi belanja modal, namun ada juga kapitalisasi yang dilakukan sehubungan dengan adanya aset yang belum tercatat, atau adanya belanja barang dan jasa yang ternyata menambah nilai suatu aset seperti sertifikat tanah menambah nilai aset tanah, atau reklasifikasi dari aset tetap yang lain ke aset tetap bersangkutan. Demikian juga dengan pengurangan nilai aset tetap, yang terjadi karena ada aset yang tidak dapat dicatat oleh pemda sebagai miliknya karena telah diserahkan ke pihak lain, ada aset yang tidak dapat dicantumkan sebagai aset tetap semula tapi harus direklasifikasikan ke aset lain, atau aset yang tidak memenuhi batas kapitalisasi aset sehingga walaupun dianggarkan dan direalisasikan sebagai belanja modal namun harus direklasifikasikan ke belanja barang dan jasa.

Setelah persoalan saldo aset pada awal Tahun 2015 rampung, kemudian Bagian Aset menghitung penyusutan untuk aset peralatan dan mesin, gedung dan bangunan, jalan irigasi dan jaringan. Perhitungan dilakukan secara manual menggunakan aplikasi microsoft excel. Menurut Kepala Bidang Aset dan Kepala Seksi Pendayagunaan, penggunaan aplikasi microsoft excel sangat membantu dan lebih akurat untuk mendapatkan nilai penyusutan dibandingkan dengan dimasukkan dalam aplikasi Simda-BMD. Karena persoalan aset di Kabupaten Bolaang Mongondow bukan aset yang berdiri tunggal, melainkan banyak aset lama yang sudah ada penambahan maupun reparasi yang menambah nilai aset. Penyusutan dilakukan menggunakan metode garis lurus. Selain itu, Simda-BMD hanya ada di Bagian Aset DPPKAD, sedangkan di SKPD belum ada Simda-BMD yang terkoneksi ke SimdaBMD DPPKAD.

\section{KESIMPULAN DAN SARAN \\ Kesimpulan}

Penelitian ini meneliti penerapan Standar Akuntansi Pemerintahan terhadap aset tetap Pemerintah Daerah Kabupaten Bolaang Mongondow. Penerapan SAP dimaksud adalah merujuk pada PP 71/2010 berbasis akrual, yang sesuai ketentuan harus dilaksanakan Pemda se-Indonesia mulai LKPD 2015. Data primer diperoleh melalui wawancara kepada 8 key person untuk mendukung data sekunder berupa LKPD dan LBMD yang berbasis akrual.

Berdasarkan hasil penelitian dan analisis, maka dapat ditarik kesimpulan sebagai berikut:

1. Penerapan SAP berbasis akrual dilakukan dengan mengkompilasi data aset dari semua SKPD Kabupaten Bolaang Mongondow, meninjau kembali nilai saldo aset per 31 
Desember 2014, menghitung akumulasi penyusutan sampai dengan 31 Desember 2014, serta menghitung beban penyusutan untuk tahun 2015.

2. Penerapan SAP berbasis akrual terhadap aset tetap Pemerintah Daerah Kabupaten Bolaang Mongondow yang telah dilakukan sesuai dengan PP 71/2010 adalah dalam hal pengukuran, pengklasifikasian, penyajian dan perhitungan penyusutan dari aset tetap. Sedangkan untuk pengakuan aset tetap belum memenuhi semua kriteria pengakuan, dan pengungkapan aset tetap belum dilakukan sebagaimana seharusnya.

3. Penerapan SAP berbasis akrual terhadap aset tetap pada Kabupaten Bolaang Mongondow masih menghadapi kendala berupa adanya selisih pencatatan antara Simda-BMD dengan Neraca, masih adanya aset yang tidak dikuasai oleh SKPD (Nilai minus aset peralatan dan mesin), masih adanya aset yang tidak diketahui keberadaannya (aset tanah yang tidak dapat ditelusuri keberadaannya), serta masih adanya aset tetap yang tanpa rincian yang jelas (Dicatat secara gabungan antara aset gedung dan bangunan, aset peralatan dan mesin, serta aset jalan, irigasi dan jaringan).

4. Kendala yang dihadapi Pemerintah Kabupaten Bolaang Mongondow tersebut sejalan dengan temuan atas hasil pemeriksaan BPK yang mengakibatkan diperolehnya opini Wajar Dengan Pengecualian untuk LKPD 2015.

5. Walaupun masih terdapat kendala, namun Kabupaten Bolaang Mongondow telah berupaya untuk dapat melaksanakan amanat PP 71/2010 berbasis akrual.

\section{Saran}

Berdasarkan Kesimpulan di atas, maka saran-saran yang dapat diberikan sebagai berikut:

1. Menyiapkan SDM yang kompeten dengan akuntansi aset dan menguasai aplikasi SimdaBMD di semua SKPD hingga ke Sekolah, Puskesmas, Pustu, dan Kelurahan, yang terkoneksi dengan Simda-BMD DPPKAD melalui jaringan LAN.

2. Melakukan inventarisasi menyeluruh (sensus aset) di semua SKPD hingga ke sekolahsekolah, Puskesmas, Pustu, dan Pemerintah Kelurahan, untuk mendapatkan kondisi aset yang sebenarnya terkait aset tetap yang tidak dapat diukur secara handal.

3. Melakukan rekonsiliasi aset dengan semua pengguna dan pemakai barang (SKPD hingga ke Sekolah, Puskesmas, Pustu, dan Kelurahan) serta dengan Bagian Akuntansi secara berkala.

4. Memperhatikan kelengkapan pengungkapan aset dalam LKPD.

Diharapkan kedepan penerapan SAP benar-benar sesuai aturan dan dilakukan oleh SDM yang cakap di seluruh bagian pemerintahan, bukan hanya oleh Bagian Aset dan Bagian Akuntansi DPPKAD, sehingga opini WTP dapat diraih.

\section{DAFTAR PUSTAKA}

Baridwan, Zaki. 2004. Intermediate Accounting. Edisi Kedelapan. Yogyakarta: BPFE. BPKP. 2016. Laporan Hasil Pengawasan BPKP Pada Provinsi Sulawesi Utara Tahun 2015. Buletin Teknis Standar Akuntansi Pemerintahan Nomor 09. 2010. Akuntansi Aset. Komite Standar Akuntansi Pemerintahan.

15. 2014. Akuntansi Aset Tetap Berbasis Akrual. Komite Standar Akuntansi Pemerintahan

18. 2014. Akuntansi Penyusutan Berbasis Akrual. Komite Standar Akuntansi Pemerintahan

Bungin, Burhan. 2015. Penelitian Kualitatif: Komunikasi, Ekonomi, Kebijakan Publik, dan Ilmu Sosial Lainnya. Jakarta: Prenada Media Group

Chan, James L., dan Qi Zhang. 2012. Government Accounting Standards and Policies. Handbook on public financial management. 
Darise, Nurlan. 2008. Akuntansi Keuangan Daerah (Akuntansi Sektor Publik). Jakarta: PT. Indeks

Diana, Anastasia dan Lilis Setiawati. 2011. Sistem Informasi Akuntansi, Perancangan, proses, dan Penerapan. Edisi 1. Yogyakarta: Andi

Djajadikerta, Hamfri. 2004. Perbandingan Pengendalian Intern dan Pengendalian Manajemen dalam Hubungannya dengan Agency Theory. Jurnal Bina Ekonomi Vol. 8 Nomor 1.

Faristina, Rosalin, 2011, Faktor-faktor yang Mempengaruhi Keandalan dan Timeliness Pelaporan Keuangan Badan Layanan Umum (Studi pada BLU di Kota Semarang).

Hanafi, M. Mamduh., dan Abdul Halim. 2007. Analisa Laporan Keuangan. Yogyakarta: UPP YKPN

Harun, Suyatno. 2008. Carut Marut Aset Negara. Majalah IAI. No. 13: 14-15

Hasfi, Nyemas., Martoyo dan Dwi Haryono. 2013. Pengelolaan Barang Milik Daerah (Suatu Studi Pada Dinas Pendapatan, Pengelolaan Keuangan dan Aset Kabupaten Sintang). Jurnal Tesis PMIS-UNTAN-PSIAN

Hilmah, Fairoza KH. 2013. Analisis Pelaksanaan Penatausahaan Dan Akuntansi Aset Tetap Pada Dpka Kota Padang. Tesis. Fakultas Ekonomi Universitas Negeri Padang. Tidak dipublikasikan

Hyndman, Noel., dan Ciaran Connolly. 2011. Accrual Accounting in the Public Sector: a Road not Always Taken. Management Accounting Research 22 (2011) 36-45. Journal.

Ibrahim, Pajaruddin. 2015. Studi Komparatif Penerapan Akuntansi Akrual Pada Pemerintah Daerah: Pendekatan Riset Campuran. Tesis. MAKSI FEB UGM Yogyakarta. Belum dipublikasikan.

Indriantoro, Nur. dan B. Supomo. 2009. Metodologi Penelitian Bisnis untuk Akuntansi dan Manajemen. Yogyakarta: BPFE.

Iskandar, 2013. Analisis Pengadaan Barang/Jasa Di Pemerintah Kota Sukabumi, Pemerintah Kota Bogor Dan Lembaga kebijakan Pengadaan Barang/Jasa Pemerintah (LKPP). Jurnal.

Jensen, M.C. dan W.H. Meckling. 1976. Theory of The Firm: Managerial Behaviour, Agency Costs and Ownership Structure. Journal of Financial Economics 3:305-360. NorthHolland Publishing Company.

KJPP. 2012. Pengelolaan Aset Daerah Kendala Perolehan Opini WTP.

Kieso, Donald E. J.J. Weygandt, dan T.D. Warfield. 2008. Intermediate Accounting, Twelfth edition. USA: Jhon Willey \& Sons, Inc. Terjemahan dalam Bahasa Indonesia oleh Emil Salim, dengan judul Akuntansi Intermediate, edisi keduabelas Jilid 2, penerbit Erlangga Jakarta

Kieso, Donald E., J.J. Weygandt, dan T.D. Warfield. 2012. Intermediate Accounting. $14^{\text {th }}$ edition. USA: Jhon Willey \& Sons, Inc.

Kuntadi, Chris. 2008. Salah Kelola Aset, LKPD Disclaimer. Majalah IAI. No. 13: 14-15.

Lestari, Prettya. dan Arief Surya Irawan. 2014. Pra Kondisi Penerapan Akuntansi Berbasis Akrual (Studi Pada Pemerintah Kabupaten Rokan Hulu). Jurnal Volume 10, November 2014.

Locke, J. 1690. An Essay Concerning the True Original, Extent and End of Civil Goverment In Social Contract. London: Oxford University Press. (1690): 84.

Mahmudi. 2011. Akuntansi Sektor Publik. Yogyakarta: UII Press.

Mardiasmo. 2009. Akuntansi Sektor Publik. Yogyakarta: Andi.

Monteiro, Bento Rodrigo Pereira., dan Ricardo Corrêa Gomes. 2013. International Experiences with Accrual Budgeting in the Public Sector. R. Cont. Fin. - USP, São Paulo, v. 24, n. 62, p. 103-112 
Mulyani, Pujianik. dan Rindah F. Suryawati. 2011. Analisis Peran dan Fungsi Sistem Pengendalian Intern Pemerintah (SPIP/PP No.60 Tahun 2008) dalam Meminimalisasi Tingkat Salah Saji Pencatatan Akuntansi Keuangan Pemerintah Daerah. Jurnal Organisasi dan Manajemen, VOl. 7, No.2, September 2011, 102-116.

Munawir, S. 2007. Analisa Laporan Keuangan. Yogyakarta: Liberty.

Myers, Margaret. 2000. Qualitative Research and The Generalizability Question: Standing Firm with Proteus. The Qualitative Report. (Vol. 4), Num. 3/4

Newberry, Susan. 2014. The Use of Accrual Accounting in New Zealand's Central Government: Second Thoughts. De Gruyter Accounting, Economics and Law - A Convivium 2014; 4(3): 283-297. Australia.

Nugraheni, Purwaniati., dan Imam Subaweh. 2008. Penerapan Standar Akuntansi Pemerintahan Terhadap Kualitas Laporan Keuangan. Jurnal Ekonomi Bisnis, No.1 Vol.13, April 2008, Hal.48-58.

Nugroho, Priyono Dwi. 2014. Pengelolaang Barang Milik Negara/Daerah (BMN/D). 17 Tahun 2007 tentang Pedoman Teknis Pengelolaan Barang Milik Daerah. 64 Tahun 2013 tentang Penerapan Standar Akuntansi Berbasis Akrual pada Pemerintah Daerah.

Peraturan Menteri Keuangan Nomor 01/PMK.06/2013 Tahun 2013 tentang Penyusutan Barang Milik Negara Berupa Aset tetap Pada Entitas Pemerintah Pusat. 166/PMK.06/2015 Tahun 2015 tentang Barang Milik Negara.

Peraturan Pemerintah Nomor 8 Tahun 2006 tentang Pelaporan Keuangan dan Kinerja Instansi Daerah.

27 Tahun 2014 tentang Pengelolaan Barang Milik Negara/Daerah.

60 Tahun 2008 tentang Sistem Pengendalian Intern Pemerintah.

71 Tahun 2010 tentang Standar Akuntansi Pemerintah. Jakarta: Salemba Empat.

Pernyataan Standar Akuntansi Keuangan Nomor 1 (Revisi 1998) Penyajian Laporan Keuangan.

1 (Revisi 2009) Penyajian Laporan Keuangan. 16 (Revisi 2011) Aktiva Tetap.

Ramadhan, Hudan Akbar. 2013. Analisis Revaluasi Aset Tetap Pada Penghematan Beban Pajak Penghasilan Pada PT. Inka Madiun. Jurnal Online Universitas Negeri Surabaya.

Revee, James M., Carl S.Warren, dan Jonathan Duchac. 2009. Principles of Accounting. South-Western: Cengage Learning

Salainti, Agnes Fanda. 2013. Evaluasi Penerapan Akuntansi Aset Tetap Pada PT. PLN (Persero) Wilayah Suluttenggo Area Manado. Jurnal EMBA, Vol.1 No.3 September 2013, Hal.890-900.

Setiadi, Doddy. 2008. Aset Merupakan Komponen Laporan Keuangan Yang Besar Pengaruhnya Terhadap Opini.

Siregar, Doli D. 2004. Manajemen Aset. Jakarta: PT. Gramedia Pustaka Utama.

Smith, W. Robert and Mark Bertozzi. 1998. Principals and Agents : An explanatory model of public budgeting. Journal of Public Budgeting and Financial Management (Fall): 325353

Sugiyono. 2013. Metode Penelitian Kuantitatif, Kualitatif dan R\&D. Bandung: CV. Alfabeta.

Sutopo, HB. 2006. Metode Penelitian Kualitatif. Surakarta: UNS Press.

Tanjung, Abdul Hafiz. 2008. Penatausahaan dan Akuntansi Keuangan Daerah. Konsep dan Aplikasi (sesuai Standar Akuntansi Pemerintahan). Bandung: Alfabeta.

Undang-Undang Nomor 1 Tahun 2004 tentang Perbendaharaan Negara. 17 Tahun 2003 tentang Keuangan Negara. 
23 Tahun 2014 tentang Pemerintahan Daerah.

36 Tahun 2008 tentang Pajak Pertambahan Nilai.

Warren, Carl S., James M. Revee, dan Philip E. Fess. 2005. Accounting. South-Western: Thomson Corporation

Williamson, Oliver. 2007. The Economics of Governance. American Economic Review, Vol.95:1-18.

Winarno, Eko Hery. 2012. Kapitalisasi Aset Tetap: Solusi Yang Belum Tergarap Optimal.

Yusup, Al Haryono. 2003. Dasar-Dasar Akuntansi. STIEYKPN

Yuwono, Sony., Dwi Cahyo Utomo, Suhaery Zein, dan Azrafiany A. R. 2008. Memahami APBD dan Permasalahannya. Panduan Pengelolaan Keuangan Daerah. Malang: Banyumedia Publishing. 